\title{
Some Laboratory and Numerical Studies on the Behaviour of Stone Columns Installed in Mumbai Marine Clay
}

\author{
Vinay Bhushan Chauhan ${ }^{1(\bowtie)}$, Yashwant A. Kolekar², \\ and Satyanarayana M. Dasaka ${ }^{1}$ \\ ${ }^{1}$ Civil Engineering Department, Indian Institute of Technology Bombay, \\ Mumbai 400076, Maharashtra, India \\ chauhan.vinaybhushan@gmail.com, \\ dasaka@civil.iitb.ac.in \\ ${ }^{2}$ Civil Engineering Department, Government College of Engineering, \\ Pune 411005, Maharashtra, India \\ yashwantkolekar@gmail.com
}

\begin{abstract}
Mumbai marine clay is problematic in nature for substructures and it needs to be strengthening before making it available for any construction activity. Out of many available geotechnical solutions, stone columns are quite handy in significantly improving the bearing capacity of marine clay, which also supplements by dissipating excess pore water pressure and reducing the settlements of clay beds under external loads. For the investigation on behavior of stone columns, marine clay was collected from the Uran site near Mumbai, India. Slurry consolidated clay beds were prepared and gravity loading mechanism was adopted to consolidate the clay beds in the laboratory. Laboratory tests were performed to ascertain the uniformity and repeatability of the clay beds by slurry consolidation. Augers of 50,75 and $100 \mathrm{~mm}$ diameter were used to bore the holes in the clay bed and aggregates were used for stone column preparation by replacement method. The static displacement controlled tests were performed on the stone column reinforced clay bed. In the present study, the loading is applied on stone column alone, as it leads to the ultimate axial capacity of stone column improved ground. Clay bed reinforced with stone column exhibits improved load-settlement response, compared to unreinforced clay beds. The improvement was very significant at higher settlements. The failure load of reinforced clay bed is around 6 times more than the unreinforced clay bed. In order to further understand the behaviour of stone column reinforced ground, numerical modeling of stone column reinforced clay bed is conducted using FLAC ${ }^{3 \mathrm{D}}$. Using the validated numerical model of the stone column, the effect of variation of the diameter of stone column on its performance was studied. From the numerical analysis and physical tests conducted in laboratory, it is observed that the stone columns with smaller diameter when subjected to vertical loading carried higher bearing pressures when compared to that of the larger diameter stone columns, which may be due to the greater confining and larger bulge formed at a depth of 2-3 times the diameter of stone columns.
\end{abstract}




\section{Introduction}

The forced intrusions in the form of aggregates/stones for the densification of the soft soil strata are commonly referred as granular columns or stone columns. Stone column construction involves partial replacement of weak subsurface soils by the vertical column of compacted granular material that usually penetrates the weak strata to reinforce the surrounding soft soil and accomplish the ground improvement, so that it can safely withstand the superimposed loads (Barksdale and Bachus 1983). These stone columns are quite handy in significantly improving the bearing capacity of marine clay, which also supplements by dissipating excess pore water pressure and reducing the settlements. The vertical axial load applied at the top of stone column also induces lateral movements in the top portion of the stone column, thereby displacing the surrounding soil leading to formation of a bulge up to a depth of 2 to 3 times the diameter of stone column below the ground. This bulge in turn, helps the stone column to develop additional load carrying capacity by generating passive pressure conditions in the surrounding soil, which provides additional confinement for the stone column through the development of hoop stresses. To ascertain the behavior of stone column, laboratory tests and numerical analysis using FLAC $^{3 \mathrm{D}}$ is performed. Also, a parametric study using physical modeling tests on the effect of variation of diameter of stone column installed in the consolidated clay bed on bearing capacity is studied in the present study.

\section{Geomaterials and Experimental Program}

The marine clay used in for the present study is obtained from the sea coast of Dronagiri, near Uran, Navi Mumbai, India. Marine clay, thus procured, is placed in specially prepared large bins of size $1.5 \mathrm{~m}$ wide, $3.5 \mathrm{~m}$ long and $2.5 \mathrm{~m}$ deep, and is covered with tarpaulin sheets throughout the year to prevent from adverse weather conditions. The particle size distribution curves of marine clay and aggregate (used for stone column) are shown in Fig. 1(a). The pre-consolidation pressure of marine clay is determined according to the BIS: 2720 Part 15 (1986) and is found to be $18 \mathrm{kPa}$, as shown in Fig. 1(b). Physical properties of marine clay used for preparation of clay bed are presented in Table 1.
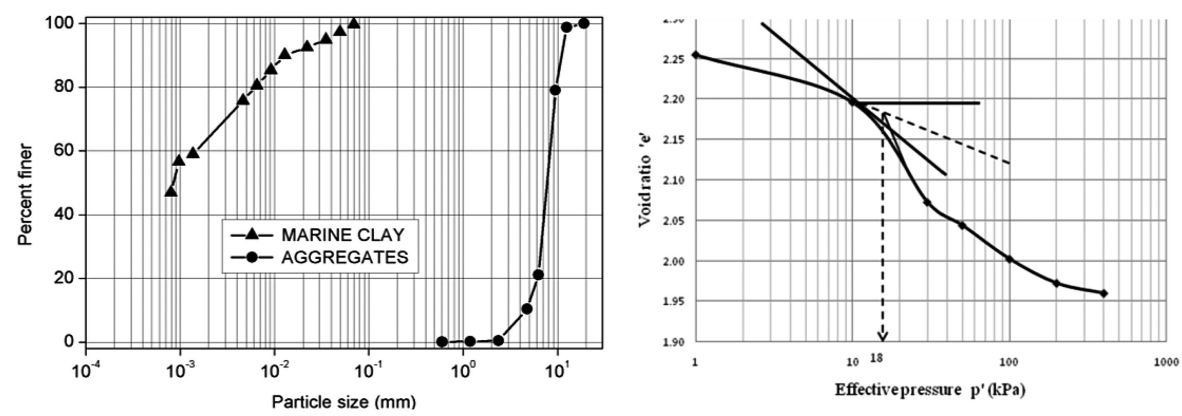

Fig. 1. (a) Grain size distribution of marine clay and aggregates (b) pre-consolidation pressure of marine clay 
Table 1. Physical properties of marine clay

\begin{tabular}{l|l}
\hline Properties & Values \\
\hline Natural moisture content, w $(\%)$ & 84 \\
\hline Field density, $\gamma\left(\mathrm{kN} / \mathrm{m}^{3}\right)$ & 14.96 \\
\hline In-situ vane shear strength, $\mathrm{S}_{\mathrm{u}}(\mathrm{kPa})$ & 8 to 9 \\
\hline Specific gravity of soil solids $\left(\mathrm{G}_{\mathrm{S}}\right)$ & 2.74 \\
\hline Liquid limit (in-situ conditions) $(\%)$ & 101 \\
\hline Liquid limit (oven dried) $(\%)$ & 51 \\
\hline Plastic limit $(\%)$ & 40 \\
\hline Plasticity index $(\%)$ & 61 \\
\hline Classification of soil & $\mathrm{OH}$ \\
\hline Pre-consolidation pressure, $\mathrm{p}_{\mathrm{c}}(\mathrm{kPa})$ & 18 \\
\hline Free swell index $(\%)$ & 31 \\
\hline
\end{tabular}

For preparing the clay bed by consolidation process, amount of water equal to 1.5 times liquid limit of the soil is added, so as to have homogeneous sedimentation (Sridharan and Prakash 2003; Murugesan and Rajagopal 2007). The soaked clay is made into slurry with the assistance of mechanical mixer. Murugesan and Rajagopal (2007), Gneil and Bouazza (2009) and Shahu and Reddy (2011) consolidated the clay slurry to form clay beds for conducting studies on stone column reinforced clay beds. Murugesan and Rajagopal (2007), Shahu and Reddy (2011) adopted dead weight consolidation. To understand the behavior and performance of stone columns in the laboratory, unit cell concept is undertaken (Barksdale and Bachus 1983; Bae et al. 2002; Ambily and Gandhi 2007; Murugesan and Rajagopal 2007; El-Garhy et al. 2011; Shahu and Reddy 2011). This unit cell is an imaginary cylindrical volume of soil with concentric stone column and the boundary of the unit cell is the extent beyond which the effect of stone column loading cannot be felt when subjected to critical loading. Unit cell (shown in Fig. 2) is adopted in the present study, which consisted of a detachable collar at the top and cylindrical tank in the bottom part. The detachable collar placed above the unit cell has dimensions of internal diameter $350 \mathrm{~mm}$, height of $250 \mathrm{~mm}$ and thickness $12 \mathrm{~mm}$. To accomplish consolidation of large clay beds simultaneously, new simplified and economical gravity loading based lever arm set-up, as shown in Fig. 3, is devised in the present study.

Pressure equal to pre-consolidation pressure is applied to the clay slurry leading to removal of excess pore water to achieve vane shear strength in the range of 8 to $9 \mathrm{kPa}$ and bring the consistency of the clay bed to that at the site and thereby simulating field conditions in the laboratory. However, Barksdale and Bachus (1983) reported that stone columns perform better in clays having undrained shear strength in the range of 15 to $50 \mathrm{kPa}$. So, the consolidation pressure is increased from $18 \mathrm{kPa}$ to $36 \mathrm{kPa}$, which resulted in undrained shear strength in the range of 20 to $22 \mathrm{kPa}$, which is in the specified range to provide better performance of stone columns. On the completion of consolidation after 30 to 35 days, the detachable collar is removed and the clay protruding above the unit cell is trimmed and leveled. 


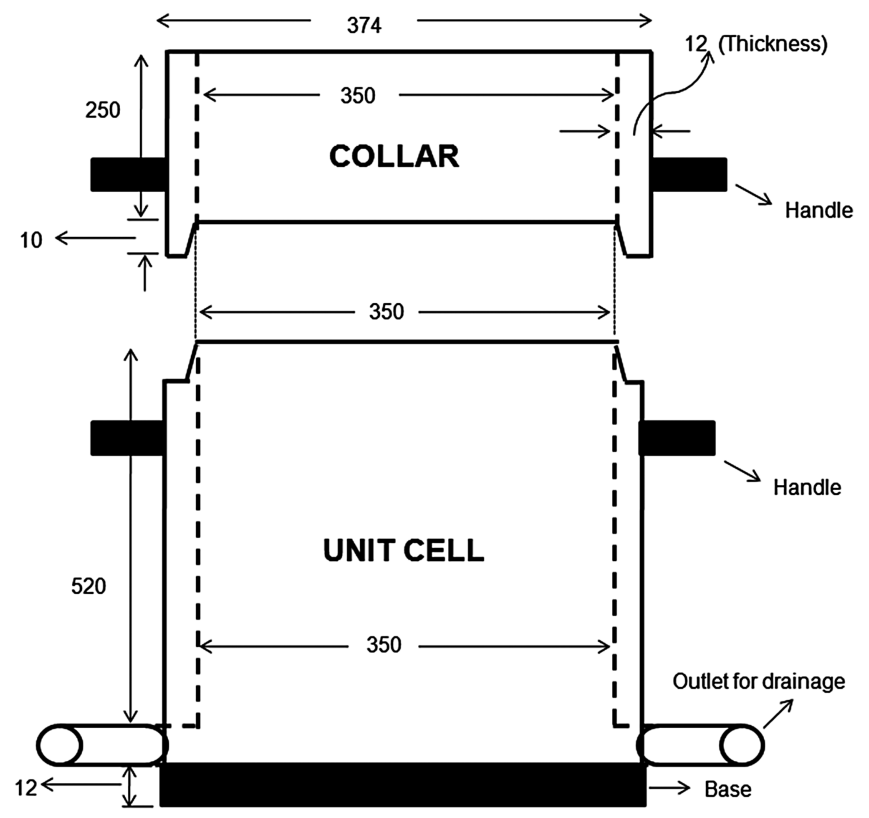

All dimensions are in $\mathrm{mm}$.

Fig. 2. Schematic layout of unit cell and collar with dimensions

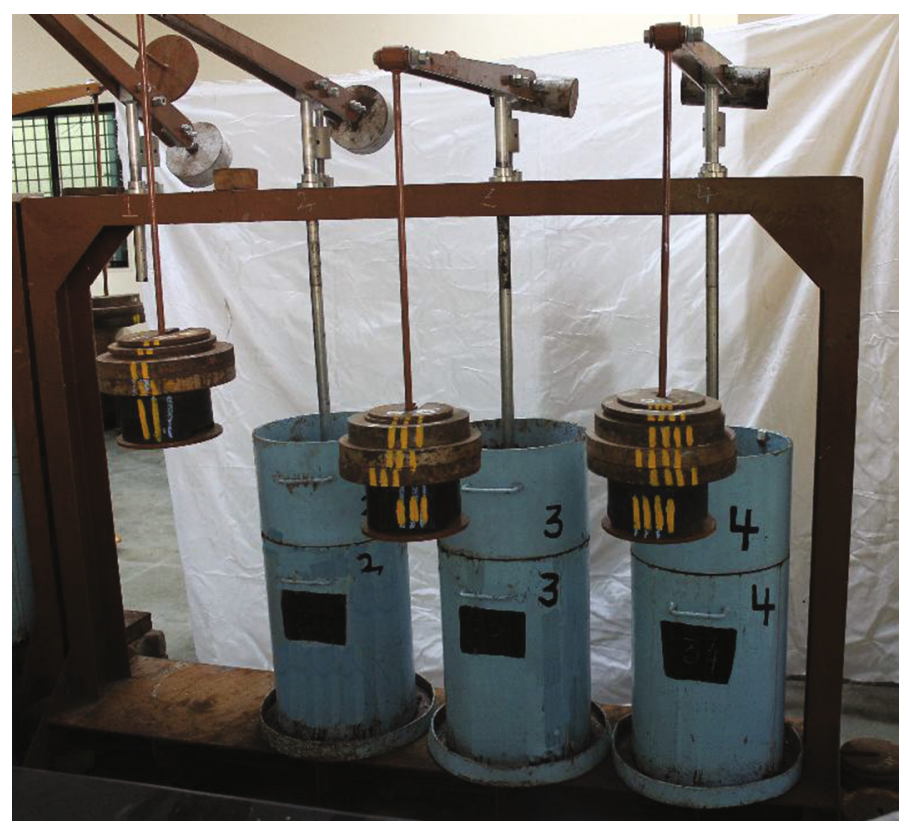

Fig. 3. Specially designed loading frame for the consolidation of clay 


\section{Parametric Study}

Bearing capacity of stone column is also a function of $\mathrm{H} / \mathrm{D}$ (height/depth) ratio of stone column. Effect of diameter and H/D ratio of the stone column on the behaviour of stone column reinforced ground has been studied by various researchers. Murugesan and Rajagopal (2007, 2008, 2009, 2010) and Ambily and Gandhi (2004, 2007) adopted $\mathrm{H} / \mathrm{D}$ ratio of unit cell greater than 1.0 and above, whereas, Malarvizhi and Ilamparuthi (2007) considered the H/D ratio of unit cell less than 1.0. Lovisa and Sivakugan (2015) observed that for doubly drained specimen with the H/D ratio up to 3 , the wall friction does not play any role and same average degree of consolidation versus time charts can be considered. Bae et al. (2002) conducted study of the stone columns having $\mathrm{H} / \mathrm{D}$ ratios as such as 5, 6, and 7. Malarvizhi and Ilamparuthi (2007) carried out similar studies and observed that with increase in H/D ratio of stone columns the settlement was reduced. So, H/D ratio for the present study is chosen 5, 6.67 and 10.

For preparation of stone column, replacement method is adopted to form fully penetrating stone columns in the consolidated clay bed using an auger (assisted by a centering plate) of diameters of $50 \mathrm{~mm}, 75 \mathrm{~mm}$ and $100 \mathrm{~mm}$ to prepare bore holes of corresponding size (Fig. 4). The aggregates, used for construction of stone columns in the marine clay bed, are procured locally. Aggregates passing through $12.5 \mathrm{~mm}$ and retained on $2 \mathrm{~mm}$ sieves are used for $100 \mathrm{~mm}$ and $75 \mathrm{~mm}$ diameter stone columns; whereas, for $50 \mathrm{~mm}$ diameter stone columns aggregates passing through $9.52 \mathrm{~mm}$ and retained on $2 \mathrm{~mm}$ sieves are used, following the recommendations of Nayak (1983). Aggregates are placed in each layer with the assistance of a hollow flexible pipe (aggregate placer) attached to the bottom of a funnel so that they reach the bottom and are not lost midway by getting stuck to the surrounding sticky marine clay. The aggregates are then compacted in 10 layers with a steel rod and unit weight of the stone column is maintained at $16 \mathrm{kN} / \mathrm{m}^{3}$. A layer of sand of $2 \mathrm{~mm}$ is placed over the surface of completed stone column. Physical properties of aggregate and sand used in preparation of stone column is shown in Table 2.

Performance of stone column reinforced clay beds are undertaken in the geotechnical laboratory using $1 \mathrm{-g}$ small scale models. For static load tests on unreinforced clay bed, a loading plate of $100 \mathrm{~mm}$ diameter is centrally placed over prepared consolidated
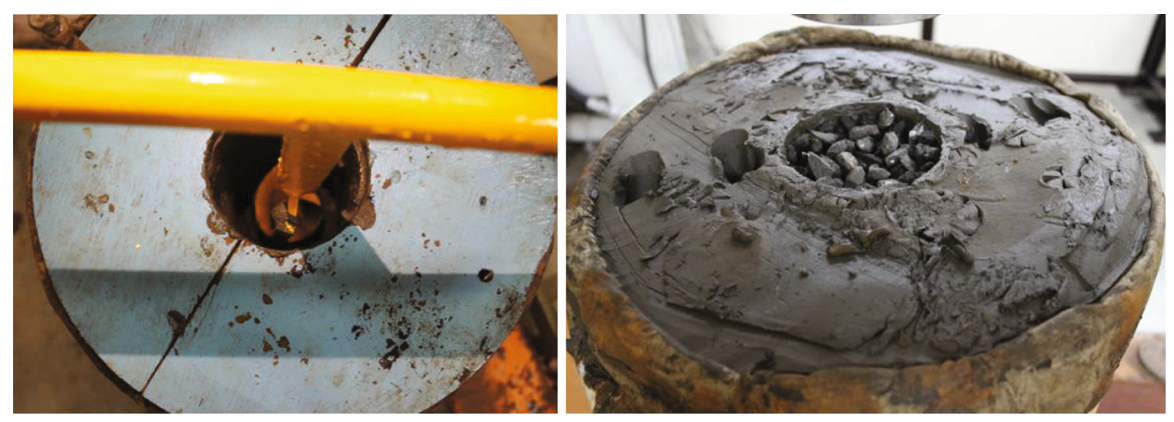

Fig. 4. Hole formed by auger and hole filled up with aggregates 
Table 2. Physical properties of aggregate and sand

\begin{tabular}{l|l|l}
\hline Properties & Aggregate & Sand \\
\hline $\mathrm{D}_{10}(\mathrm{~mm})$ & 4.5 & 0.65 \\
\hline $\mathrm{D}_{30}(\mathrm{~mm})$ & 7.0 & 0.80 \\
\hline $\mathrm{D}_{60}(\mathrm{~mm})$ & 8.5 & 1.2 \\
\hline Coefficient of uniformity, $\mathrm{C}_{\mathrm{u}}$ & 1.28 & 1.85 \\
\hline Coefficient of curvature, $\mathrm{C}_{\mathrm{c}}$ & 1.89 & 0.82 \\
\hline Classification as per USCS & Poorly graded gravel $(\mathrm{GP})$ & Poorly graded sand (SP) \\
\hline Internal friction angle (Degrees) & $41^{\circ}$ & - \\
\hline Unit weight $\left(\mathrm{kN} / \mathrm{m}^{3}\right)$ & 16 & - \\
\hline
\end{tabular}

clay bed and loading is applied at a constant displacement rate of $1.2 \mathrm{~mm} / \mathrm{min}$ up to $50 \mathrm{~mm}$ displacement. Pressure-settlement response of clay beds consolidated at $18 \mathrm{kPa}$ and $36 \mathrm{kPa}$ is studied. For static load tests on reinforced clay bed, loading plates of $12 \mathrm{~mm}$ thick and diameter equals to that of the stone column of diameter $100 \mathrm{~mm}$, $75 \mathrm{~mm}$ and $50 \mathrm{~mm}$ are studied in the present study. Loading procedure is similar to that of unreinforced clay bed. In the present studies, results from three tests carried out on the consolidated clay bed in unit cell subjected to $36 \mathrm{kPa}$ consolidation pressure are presented.

\section{Numerical Analysis}

Clay beds with stone column having dimensions similar to laboratory test are analysed using finite difference analysis tool $\mathrm{FLAC}^{3 \mathrm{D}}$. Elastic modulus of aggregate, clay and steel are taken as $45 \mathrm{MPa}, 4 \mathrm{MPa}$ and $180 \mathrm{GPa}$. Poisson's ratio of aggregate, clay and steel are taken as $0.3,0.45$ and 0.29 . Figure 5 shows the numerical grid generated to simulate the unreinforced and reinforced clay beds placed inside steel tank. Clay bed and aggregate are modelled as an elasto-plastic material following Mohr-Coulomb failure criterion and tank is modelled as elastic material. The steel container consisting of clay bed and stone column is modelled numerically, and the model is fixed at bottom to represent the physical test conditions. Very fine grid is chosen for the simulation of unreinforced and reinforced clay bed model as shown in Fig. 5. The interface (shown in Fig. 6) between stone column and clay is modelled as linear spring-slider system with interface shear strength defined by the Mohr-Coulomb failure criterion. The normal stiffness $\left(k_{n}\right)$ and shear stiffness $\left(k_{s}\right)$ of the interface are taken as per guidelines of Itasca (2011). Interface parameters, $k_{n}$ and $k_{s}$, have been assigned a value of $6 \times 10^{8} \mathrm{kN} / \mathrm{m}^{2} / \mathrm{m}$ at the periphery of stone column. In the present analysis, diameter of stone column is varied as 50, 75 and $100 \mathrm{~mm}$ and displacement at a constant incremental displacement is applied up to $50 \mathrm{~mm}$ to observe the load settlement behaviour of the same and results are validated with physical test results. 

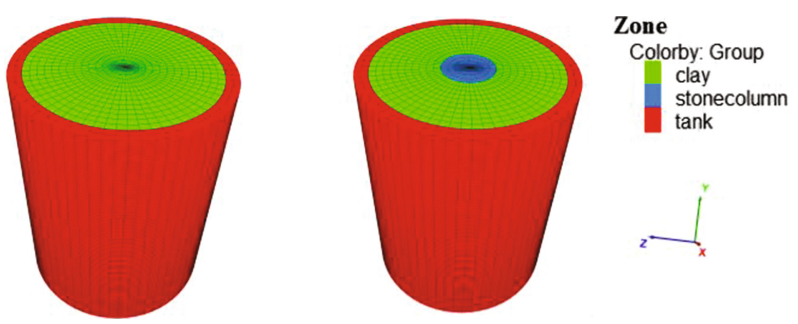

Fig. 5. Numerical grid for unreinforced and reinforced clay bed

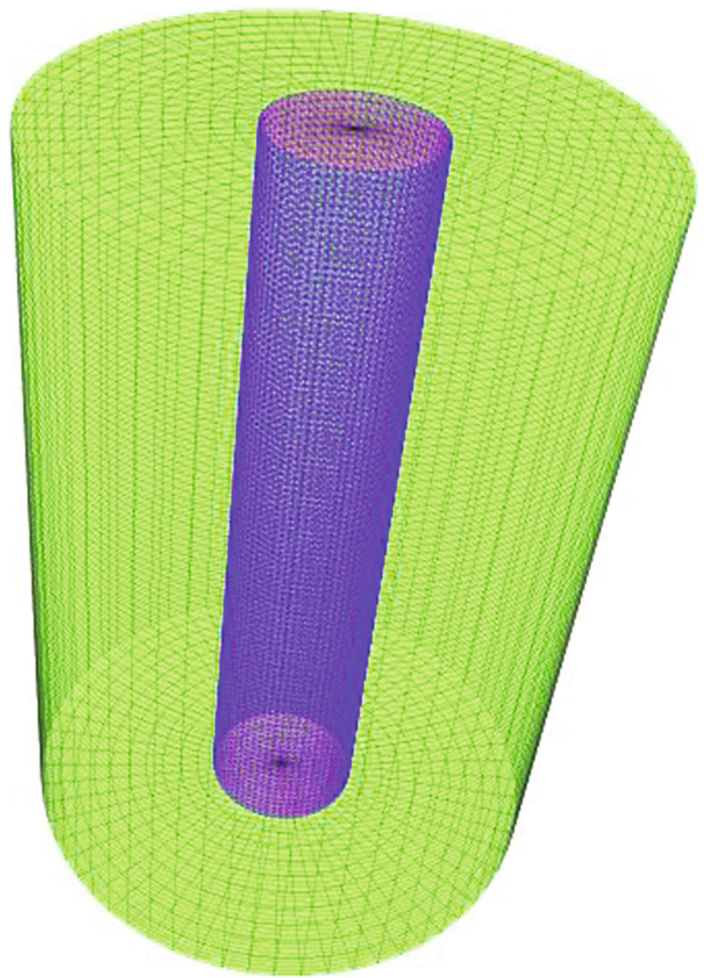

Fig. 6. Interface between stone column and clay bed in FLAC ${ }^{3 \mathrm{D}}$

\section{Results and Discussion}

\subsection{Effect of Consolidation Pressure}

With doubling of the consolidation pressure from $18 \mathrm{kPa}$ to $36 \mathrm{kPa}$, there is 1.48 times increase in the bearing pressure at settlement of $50 \mathrm{~mm}$ for the unreinforced clay beds as shown in Fig. 7(a). 


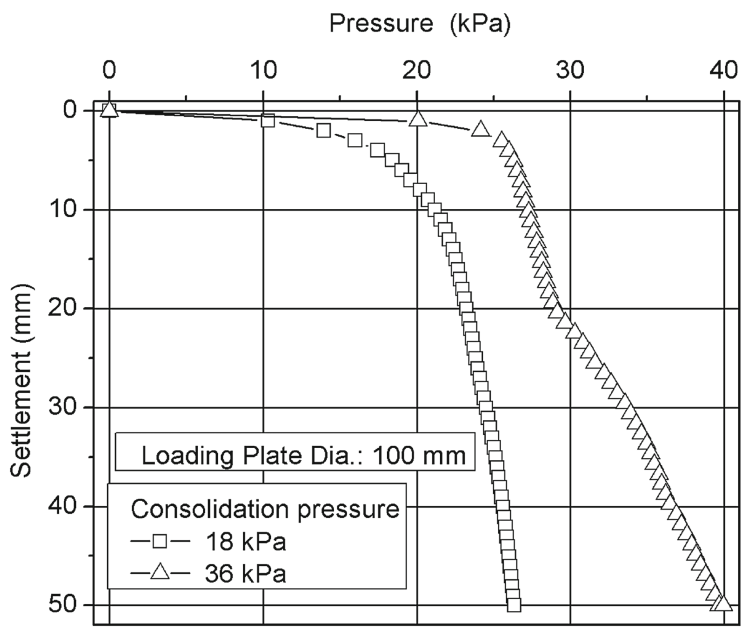

(a)

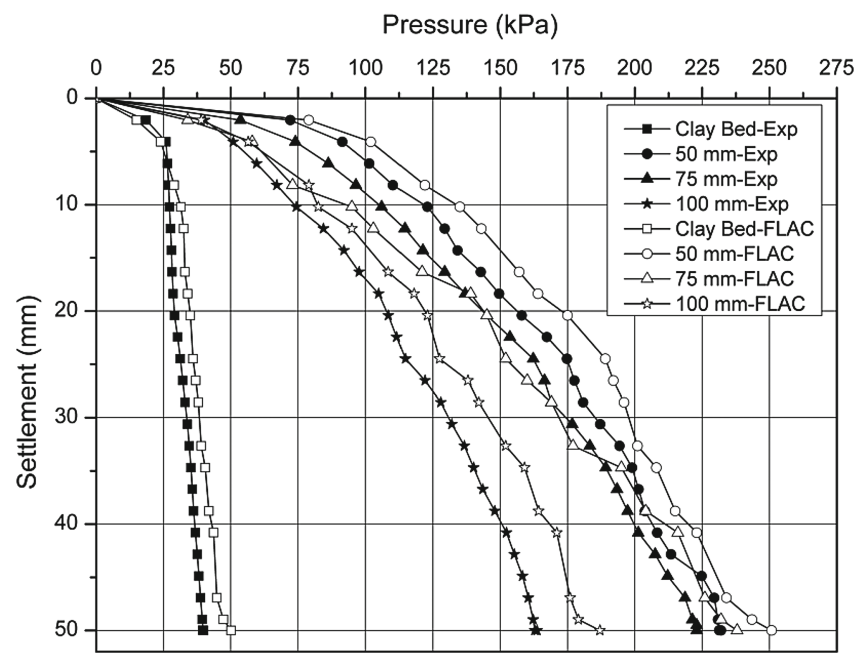

(b)

Fig. 7. Pressure-settlement response of (a) unreinforced clay beds consolidated at $18 \mathrm{kPa}$ and $36 \mathrm{kPa}$ (b) reinforced clay bed with different diameter of stone columns

\subsection{Influence of Diameter of Stone Column}

The diameter of stone column has significant effects the behaviour and performance of stone column reinforced clay bed. There is marked improvement in the bearing pressure of the stone column reinforced clay bed over the unreinforced clay bed. The increase in bearing pressure of clay bed with 100,75 , and $50 \mathrm{~mm}$ diameter stone columns is $4,5.5$ and 5.8 time that of unreinforced clay bed, respectively, as shown in 
Fig. 7(b), at $50 \mathrm{~mm}$ settlement. It is observed that the experimental results for the clay bed and the clay bed reinforced with different diameter stone columns are in tandem with the numerical results. However, the numerical results are slightly on the higher side. From the numerical analysis, bulging contours of stone column in lateral directions $(\mathrm{x}$ and $\mathrm{z}$ ) are presented for $100 \mathrm{~mm}$ diameter stone column in Fig. 8. It can be noted from these figures that the bulging of stone column extends up to a depth of 2D of stone column, where D is the diameter of the stone column. Similarly, lateral strain up to $15 \%$ is observed in the stone column, which resulted in creating passive pressure in clay bed, and led to the increase in load bearing capacity of stone column.

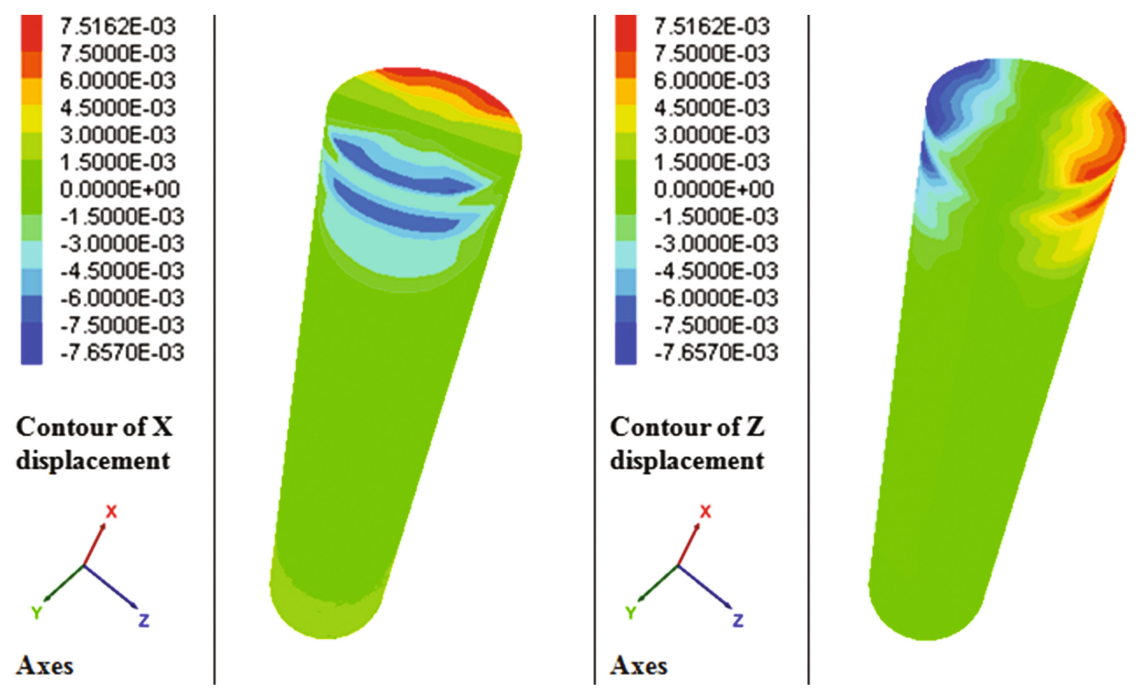

Fig. 8. Displacement contours of stone column of $100 \mathrm{~mm}$ diameter

\subsection{Improvement Factor $\left(\mathrm{I}_{\mathrm{f}}\right)$}

The performance improvement of the stone column reinforced clay bed is represented using a non-dimensional parameter - bearing pressure improvement factor $\left(I_{f}\right)$, which is the ratio of footing pressure $\left(\mathrm{q}_{\mathrm{c}}\right)$ for a reinforced clay bed at a given settlement to the footing pressure $\left(\mathrm{q}_{\mathrm{o}}\right)$ for an unreinforced clay bed, at the same settlement, as defined below:

$$
I_{f}=q_{c} / q_{o}
$$

Improvement factor for the stone column reinforced clay bed is presented in Table 3 . Briefly discuss the results shown in Table 3. 
Table 3. Improvement factor for the stone column reinforced clay bed

\begin{tabular}{l|l|l|l|l}
\hline $\begin{array}{l}\text { Test } \\
\text { description }\end{array}$ & $\begin{array}{l}\text { Bearing pressure at } \\
25 \mathrm{~mm} \text { settlement } \\
(\mathrm{kPa})\end{array}$ & $\begin{array}{l}\text { Improvement } \\
\text { factor }\left(\mathrm{I}_{\mathrm{f}}\right)_{25}\end{array}$ & $\begin{array}{l}\text { Bearing pressure at } \\
50 \mathrm{~mm} \text { settlement } \\
(\mathrm{kPa})\end{array}$ & $\begin{array}{l}\text { Improvement } \\
\text { factor }\left(\mathrm{I}_{\mathrm{f}}\right)_{50}\end{array}$ \\
\hline $\begin{array}{l}\text { Unreinforced } \\
\text { clay bed }\end{array}$ & 32 & - & 40 & - \\
\hline $\begin{array}{l}\text { Reinforced } \\
\text { clay bed } \\
50 \mathrm{~mm}\end{array}$ & 201 & 6.3 & 233 & 5.8 \\
\hline $\begin{array}{l}\text { Reinforced } \\
\text { clay bed } \\
75 \mathrm{~mm}\end{array}$ & 164 & 5.1 & 223 & 5.6 \\
\hline $\begin{array}{l}\text { Reinforced } \\
\text { clay bed } \\
100 \mathrm{~mm}\end{array}$ & 115 & 3.6 & 164 & 4.1 \\
\hline
\end{tabular}

\section{Conclusions}

In the present study, the behaviour of stone columns installed in very soft cohesive soil (marine clay) and subjected to static loads is studied using small scale models tested at $1-\mathrm{g}$ conditions. Slurry consolidation method is adopted to prepare clay beds, simulating the natural conditions. The slurry consolidation is carried out in the unit cell itself. Stone column reinforced clay beds are subjected to static load to ascertain their performance by varying their diameter. In the present study, stone columns of diameters $50 \mathrm{~mm}, 75 \mathrm{~mm}$ and $100 \mathrm{~mm}$ are used to understand the behavior of stone column reinforced clay beds subjected to static loading. A validated numerical model is also developed in FLAC ${ }^{3 \mathrm{D}}$ to have better insight into the stone column behavior. The following conclusions are drawn from the present study.

1. With doubling of the consolidation pressure there is 1.48 times increase in the bearing pressure at settlement of $50 \mathrm{~mm}$ for the unreinforced clay beds.

2. With the increase in the diameter of stone column there is decrease in the bearing pressure of stone column which is attributed to the confining stresses, which is more in smaller diameter stone columns.

3. Clay bed reinforced with stone column exhibits improved load-settlement response, compared to unreinforced clay beds. The improvement was very significant at higher settlements. The failure load of reinforced clay bed is around 6 times more than the unreinforced clay bed, which is in tandem with the observations of other researchers. It is noted that only top portion of the stone column, i.e. depth ranging from 2 to 3 times diameter of stone column, undergoes bulging, and influencing the response of stone column to external loads.

4. The numerical simulation results show bulging at a depth of $2 \mathrm{D}$ which develops passive pressure conditions at the interface. 


\section{References}

Ambily, A.P., Gandhi, S.R.: Experimental and theoretical evaluation of stone column in soft clay. In: Proceedings of ICGGE-2004, IIT Bombay, India, pp. 201-206 (2004)

Ambily, A.P., Gandhi, S.R.: Behaviour of stone columns based on experimental and FEM analysis. J. Geotech. Geoenviron. Eng. 133(4), 405-415 (2007)

Bae, W.S., Shin, W.S., An, B.C.: Behaviours of stone column improved with stone columns. In: Chung, S., Kashiwagi, S., Hong, S.W. (eds.) Proceedings of the 12th International Offshore and Polar Engineering Conference, Kitakyushu, Japan, pp. 675-678, 26-31 May 2002

Barksdale, R.D., Bachus, R.C.: Design and construction of stone columns. Report No. FHWA/RD-83/026, Federal Highway Administration, Washington, D.C., USA (1983)

BIS: 2720 (Part-15): Methods of Test for Soils-Determination of Consolidation Properties. Bureau of Indian Standards, New Delhi (1985)

El-Garhy, B., Maraie, M., Youssef, A.: Behaviour of model footings resting on soft clay reinforced by floating granular piles: experimental study. Int. J. Geotech. Eng. 5(4), 415-424 (2011)

FLAC 3D (5.0), Itasca (2011)

Gniel, J., Bouazza, A.: Improvement of soft soils using geogrid encased stone columns. Geotext. Geomembr. 27(3), 167-175 (2009)

Lovisa, J., Sivakugan, N.: Tall oedometer: method to account for wall friction. Int. J. Geomech. 15, 1-9 (2015). 04014045

Malarvizhi, S.N., Ilamparuthi, K.: Comparative study on the behaviour of encased stone column and conventional stone column. Soils Found. 47(5), 873-886 (2007)

Murugesan, S., Rajagopal, K.: Model tests on geosynthetic encased stone columns. Geosynthetics Int. 14(6), 346-354 (2007)

Murugesan, S., Rajagopal, K.: Performance of encased stone columns and design guidelines for construction on soft clay soils. In: Li, G., Chen, Y., Tang, X. (eds.) Proceedings of the 4th Asian Regional Congress on Geosynthetics, Shanghai, China, pp. 729-734 (2008)

Murugesan, S., Rajagopal, K.: Shear load tests on stone columns with and without geosynthetic encasement. Geotech. Test. J. ASTM 32(1), 35-44 (2009)

Murugesan, S., Rajagopal, K.: Studies on the behaviour of single and group of geosynthetic encased stone columns. J. Geotech. Geoenviron. Eng. ASCE 136(1), 129-139 (2010)

Nayak, N.V.: Recent advances in ground improvements by stone columns. In: Proceedings of Indian Geotechnical Conference, Madras, vol. 1, p. V-19 (1983)

Shahu, J.T., Reddy, Y.R.: Clayey soil reinforced with stone column group: model tests and analyses. J. Geotech. Geoenviron. Eng. 137(12), 1265-1274 (2011)

Sridharan, A., Prakash, K.: Self-weight consolidation: compressibility behaviour of segregated and homogeneous fine grained sediments. Mar. Georesour. Geotechnol. 21(2), 73-80 (2003) 